Digitonin perfusion in the study of metabolic zonation of the rat liver: potassium as an intracellular concentration reference.

Quistorff, Bjørn

Published in:

Biochemical Society Transactions

Publication date:

1987

Document version

Publisher's PDF, also known as Version of record

Citation for published version (APA):

Quistorff, B. (1987). Digitonin perfusion in the study of metabolic zonation of the rat liver: potassium as an intracellular concentration reference. Biochemical Society Transactions, 15(3), 361-363. 


\section{Digitonin perfusion in the study of metabolic zonation of the rat liver: potassium as an intracellular concentration reference}

\section{BJØRN QUISTORFF \\ Department of Biochemistry, University of Copenhagen. The Pamum Institule, Blegdamsvej 3, 2200 Denmark}

The mammalian liver microcirculation seems to be uniquely organized in order to create maximum difference of the biochemical milieu to which the upstream (periportal) and downstream (perivenous) parenchymal cells are exposed. Indecd the existence of a subdivision of hepatocytes in zones of different metabolic function, long predicted by enzyme zonation studies (for a review, see Jungermann \& Kalz, 1982), has now been documented in direct studies for gluconcogenesis, urea synthesis and glutamine synthesis (Häussinger, 1983; Quistorff; 1985; Pösö et al. 1986; Quistorff et al., 1986). However, an understanding of the physiological implications of this functional subdivision is still lacking.

Since such zonation can be expected to be closely related to the perfusion pattern of the liver, a techniyue which utilizes the direction of liver perfusion as the discriminatory principle in the selective study of periportal and perivenous cells would appear to bc optimal. The digitonin perfusion technique is based on this principle (Quistorff et al., 1985). The technique has developed in two dircctions: either for direct use of the eluate in the study of enzyme and metabolite contents of the periportal and the perivenous zone (Quistorff \& Grunnet, 1987) or using the digitonin perfusion for selective destruction of part of the microcirculation, followed by isolation of hepatocyles from the non-affected part by standard collagenase perfusion techniques (Lindros \& Pentlilä, 1985; Quistorff, 1985: Quistorff et al., 1986).

This paper discusses the mode of action of the digitonin perfusion and also introduces $\mathrm{K}^{+}$as a reference substance, allowing estimation of enzyme activity distribution within the micsocirculatory unjt of the liver as well as intracellular concentrations of cytosolic metabolites.

\section{Methods}

The data presented were obtained with the dual-digitoninpulse perfusion technique, described in detail in Quistorff \& Grunnet (1987). The technique involves a brief digitonin pulse ( $10 \mathrm{~s}$ of digitonin, $4 \mathrm{mg} / \mathrm{ml}$ in Krebs-Henselict buffer, at $12 \mathrm{ml} / \mathrm{min}$ ) followed by an immediate switching of flow direction and washout without digitonin at $20 \mathrm{ml} / \mathrm{min}$, sampling the eluate for enzyme and for metabolite measurements. The samc procedure was repeated with the opposite flow direction after an interval of $30 \mathrm{~s}$, obtaining thereby both periportal and perivenous eluate of the same liver. Routincly a liver biopsy was taken before the digitonin treatment (right lower lobc; Quistorff, 1985). $\mathrm{K}^{+}$and $\mathrm{Na}^{+}$ were measured by flame pbotometry with the samples diluted in $\mathrm{LiCl}$. Protein was measured according to Lowry et al. (1951).

\section{Results}

Fig. 1 shows a simplified model of the liver microcirculation, with only two populations of hepatocytes and no zone of mixed cells. While such a model assuming a stepgradient is appropriate for the distribution of some enzyınes likc glutamine synthase (Gebhardt \& Mecke, 1983) and in the sense that the dual-digitonin-pulse technique samples eluate from only inlet and outlet cells, it may not be adequate for enzymes or metabolites which are nol distributed according to a discontinuous periportal-perivenous activity or concentration gradient. In Fig. I $(b)$ a brief pcriportal digitonin pulse has been applied with the result of partial destruction of the periportal area and clution of cytosolic material from the destroyed cells. If, at this stage, collagenase isolation of the remaining hepatocytes were carried out (Quistoff. 1985). the resultant cell preparation would be enriched in perivenous cells, with two-thirds perivenous cells and one-third periportal cells, as demonstrated by the exanple in the Figure. Conversely, with a perivenous digitonin pulse to the liver (Fig. 1c) followed by collagenase cell isolation, a cell preparation enriched in periportal cells would be oblained.

Thus while the digitonin cell isolation technique can only produce either periportal or perivenous cell preparations from one liver in addition to the initial periportal or perivenous eluate, respectively, the dual-digitonin-pulse lcchnique gives perivenous as well as pcriportal eluate from the same liver, but no cclls.

By measuring the activity of the marker enzymes glutamate dehydrogenase, glucose-6-phosphatase and amyloglueosidase in the eluate, we know that under the present experimental conditions the contamination with mitochondrial, endoplasmic reticulum and lysosomal material is insignificant (Quistorff et al., 1985; Quistorff \& Grunnet, 1987),

The cluted cytosolic material is diluted by the perfusate. Assuming a cytosolic $\mathrm{K}$ concentration of $160 \mu \mathrm{mol} / \mathrm{ml}$ (Williams \& Woodbury, 1971; Christensen \& Folkc, 1984) the actnal dilution may be calculated as shown in Table 1. Under the present experimental conditions the most concentrated samples of cytosolic material were eluted in the fractions $1025 \mathrm{~s}$ at approx. 10-fold dilution. Note that perivenous eluates were significantly more diluted than periportal eluates. Similar dilution factors inay bc obtained by a different method (Quistorff \& Grunnet, 1987).

Table 2 shows data on protein, $\mathrm{K}^{+}$and $\mathrm{Na}^{+}$concentration in the eluate from both the periportal and the perivenous part of the liver. $\mathrm{K}^{+}$and protein concentration in the eluate increased with a broad maxinum in the $10-15 \mathrm{~s}$, $15-20 \mathrm{~s}$ and $20-25 \mathrm{~s}$ fractions lor both periportal and perivenous eluate. In Table 2 these three fractions are thereforo combined. Note that both $\mathrm{K}^{\div}$and protein werc significantly lower in perivenous eluate. Parallel with the $\mathrm{K}^{+}$release there

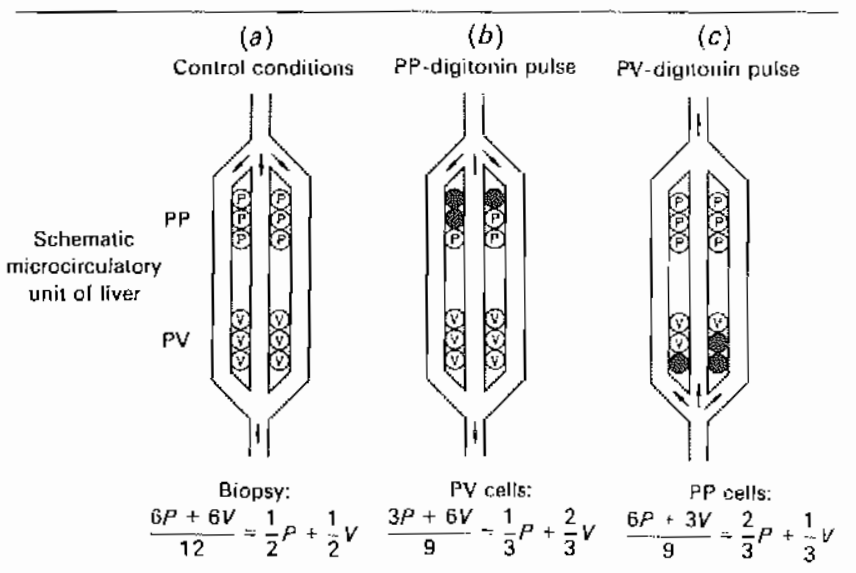

Fig. 1. Model of liver microcirculation during digitonin perfusion

The model assumes two populations of hepatocytes, periportal (PP) and perivenous (PV), cach of which is homogencous with respect to the parameter in question, but not necessarily of the same size. The Figure shows an cxample of hepatocyte isolation from the liver after a pulse of digitonin was given to partiaily destruct either the PP area $(b)$ or the PV arca $(c)$ (Quistorff. 1985). The catculations bclow demonstrate the "purity of the cell preparation obtained in the two cases. 
Table 1. Dilution of the periportal and perivenous cyosol shed with the dhat-digitonin-pulse perfision technique

Livers of red, female Wistar rats were perfused by the dual-digitonin-pulse techinique (perfusion scheme I3 in Fig. I of Quistorff \& Grunnet, 1987) with digitonin (4 mg/ml). Eight periportal and eight perivenous cluate fractions were collested over the time intervals indicaled alter digitonin treatment. The dilution factors of the eluted cylosol given for each fraction were calculated from the $\mathrm{K}^{+}$coucentration measured in the eluate, assuming an intracellular $\mathrm{K}^{+}$of 160 mol $\mathrm{mi}$ of cylosol, and using as blank the $\mathrm{K}^{\prime}$ conceulration in the Krebs $\cdots$ Henselcit perfusatc. Results are means \pm S.D. $(n=8)$. Statistical significance (paired $f-$ est): $* p<0.01$ periportal cluate versus perivenous eluatc.

\begin{tabular}{|c|c|c|c|c|c|c|c|c|}
\hline \multirow[b]{2}{*}{ Elution frac } & \multicolumn{8}{|c|}{ Dilution factor } \\
\hline & $\ldots 05 \mathrm{~s}$ & $5-10 s$ & $10-1.5 \mathrm{~s}$ & $1520 \mathrm{~s}$ & $20-25 \mathrm{~s}$ & $2530 \mathrm{~s}$ & $3(1)-3$ is & $3.540 \mathrm{~s}$ \\
\hline Periportal cytosol & $\begin{array}{l}209 \\
\perp \quad 75.4\end{array}$ & $\begin{array}{l}24.8 \\
\pm 34.6\end{array}$ & $\begin{array}{l}8.92 \\
\pm 1.58\end{array}$ & $\begin{array}{l}8.41 \\
+3.42\end{array}$ & $\begin{array}{l}11.2 \\
\pm 1.22\end{array}$ & $\begin{array}{l}14.6 \\
\pm 1.35\end{array}$ & $\begin{array}{l}18.6 \\
\pm 1.5 !\end{array}$ & $\begin{array}{l}29.9 \\
=3.51\end{array}$ \\
\hline Perivenous cytosol & $\begin{array}{l}143 \\
\pm 147\end{array}$ & $\begin{array}{l}30.6 \\
\pm 9.45\end{array}$ & $\begin{array}{l}12.8^{*} \\
\pm 2.40\end{array}$ & $\begin{array}{l}15.0^{*} \\
\pm 1.57\end{array}$ & $\begin{array}{l}20.7^{*} \\
\pm 2.81\end{array}$ & $\begin{array}{l}29.1 * \\
\pm \quad 5.58\end{array}$ & $\begin{array}{l}3 \times .3^{*} \\
\pm 10.2\end{array}$ & $\begin{array}{l}+7.7^{*} \\
=12.3\end{array}$ \\
\hline
\end{tabular}

$* P<0.01$ periportal eluate versus perivenous eluate.

was an uptake of $\mathrm{Na}^{+}$by the liver, peaking also in the $10-25 \mathrm{~s}$ fraction and consistently approx. $2-3 \mu \mathrm{mol} / \mathrm{ml}$ larger

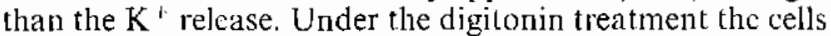
are losing anions in the form of metabolites, notably ATP, ADP and $\mathrm{P}_{\mathrm{i}}$ (Quistorff \& Grunnet, 1987), and it is not known at present which anions compensate lor the "extra" $\mathrm{Na}^{+}$uptake observed. Interestingly, the ratio between protein and $\mathrm{K}^{+}$in the cluate (Table 2 , column 4 ), was nearly constant, approx. $0.6 \mathrm{mg} / \mu \mathrm{mol}$ of $\mathrm{K}^{+}$during the elution without statistically significant difference between periportal and periyenous eluate.

\section{Discussion}

Mode of action of the digitonin perfusion technique. The following observations have been made. Continuous infusion of digitonin caused complete decolorization of the liver under appropriate conditions. The decolorization process may be followed by visual inspection of the surface of the liver while slowly progressing from periportal arcas towards perivenous outlets. The decolorization pattern thus formed on the liver surface unequiyocally reflects whether digitonin perfusion was started with normal perifusion direction or with retrograde perfusion (Quistoff et al., 1985; Lindros \& Penttilä, 1985). It was further shown that at $20 \mathrm{ml}$ of digitonin/min $(6 \mathrm{mg} / \mathrm{ml})$ the liver almost completely cleared the perfusate of digitonin for an interval of about $50 \mathrm{~s}$ after which, however, the digitonin concentration in the effluent sharply increased lowards $6 \mathrm{mg} / \mathrm{ml}$. The amount ol digitonin delivered during the time interval of near-complete clcarance corrclated well with the total amount of cholesterol in the liver (Quistorff et al., 1985). Finally, histological examination of sections of liver, stained with the chromotrope, Aniline Blue, (Lillie, 1940) and fixed in phosphatebuffered formaldehyde (Poulsen \& Christoffersen, 1979) at various stages during digitonin $(2 \mathrm{mg} / \mathrm{ml})$ perfusion, showed that the area of destruction was always associated with the direction of entry of the digitonin (periportal or perivenous region) and that initially the degree of destruction was evenly distributed over the section. However, when more than about one-quarter of the total liver was affected. disynchronization ol flow in different microcirculatory units wals apparent (B. Quistorff. N. Grunnet \& O. Nbrechtsen. unpublished work).

These facts taken together strongly suggest that the mode of action of the digitonin perfusion is a titration of the cholesterol content of the hepatocytcs along the sinusoid, in such a way that the 'digitonin front' moves through the sinusoids at a speed determined hy the delivery of digitonin relative to the amount of cholesterol present. Since $70 \%$ of total cholesterol is in the plasma membrane (de Duve. 1971) this is likely to be the prime target of the digitonin action. leaving the hepatocytes 'nude', stripped of the plasma membrane (Cook ef al., 1983). This notion is supported by the lact that even the completely decolorized liver, having lost $>80 \%$ of its protein and soluble metabolite content. has entirely maintained its macroscopic appearance (Quistorff et al., 1985).

$K^{+}$as an endogenous concentration reference substance. In a previous paper we discussed that the cvaluation of a periportal/perivenous gradient of an enzyme based on comparison of specific activities will rely on whether or not total protejn is zonated (Quistorff \& Grunnet, 1987). The dala in that work as well as the data reported here (Table 2) indeed suggest a higher periportal protein concentration. However, since the absolute concentrations developed in the eluatc to some extent depend upon the scquence of perfusion (porta $\rightarrow$ cava lollowed by cava $\rightarrow$ porta or vice versa: Quistorff \& Grunnet, 1987), and since also significant interanimal variation is seen in this respect, it becomes important to solve the reference problem, e.g. by finding a substance for which the absolutc zonal distribution is known. No such substance is ycl known: however, $\mathrm{K}^{+}$might he a good candidate, primarily because of its very high intracellular concentration, which makes significant changes (on a percentagc scale) unlikely under physiological conditions. Furthermore, $\mathrm{K}^{+}$is for the same rcason unlikely to he

Table 2. $\mathrm{K}^{\prime}, \mathrm{Na}^{\prime}$ and protein elution with the dual-digitonin-pulse perfusion techique

Liver perfusion and fraction collection were as described in Table 1 . The combined data of the fractions $10 \quad 15 \mathrm{~s}, 15-20 \mathrm{~s}$ and $20-25 \mathrm{~s}$ are given as means $\pm s .1) .(n=8)$. $\mathrm{Na}^{+}$and $\mathrm{K}^{i}$ values arc corrected for the contenl of these ions in the Krebs-Henseleit perfusion medium. Stalistical significance: (paired $l$-lest): $* P<0.05$ periportal eluate versus perivenous eluate.

\begin{tabular}{|c|c|c|c|c|}
\hline & $\underset{(\mu \mathrm{mol} / \mathrm{ml})}{\mathrm{K}^{+}}$ & $\begin{array}{c}\mathrm{Na}^{\prime} \\
(\mu \mathrm{sul} / \mathrm{ml})\end{array}$ & $\begin{array}{l}\text { Protein } \\
\text { (mg/ml) }\end{array}$ & $\begin{array}{c}\text { Protein: } \mathrm{K}^{+} \\
\left(\mathrm{mg} / / \mathrm{m} \text { ol of } \mathrm{K}^{+}\right)\end{array}$ \\
\hline & $14.9 \pm 1.72$ & $-17.8 \pm 3$ & 9 & $0.62+$ \\
\hline Perivenous eluale & $10.3 \pm 1.50 *$ & $-12.6 \pm 2.85^{*}$ & $5.62 \pm 0.72^{*}$ & $0.52 \mp 0.06$ \\
\hline
\end{tabular}

$* P<0.05$ periporal eluate versus perivenous eluate. 
2. 4 - wernify zonated, although this is not known at present thoepting $\mathrm{K}^{-}$as a non-zonated concentration reference 42: e d a

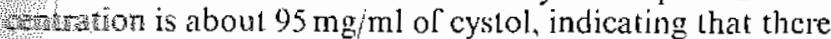
6. wo significant difference in cy tosolic protein concentration Cetween periportal and perivenous cells.

Ertination of enzyme distribution in the liver microcircu-

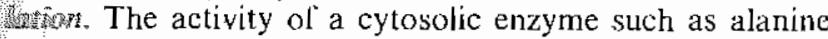
umbinotransferase in the initial biopsy will be the weighted sam of the activity in periportal and perivenous cells. In an experiment with the dnal-digitonin-pulse technique we usually have data for the specific activity of a particular enzyme both from the initial biopsy and from the periportal and perivenous efuates. However, since the periportal and perivenous activity measured in the cluates is expressed per $\mathrm{mg}$ of cytosolic protein, while the activity in the biopsy is expressed per ing of total protein, a conversion factor is needed. Hrom the cytosolic eluates we obtain the average value of $\mathrm{mg}$ of cytosolic protein $/ \mu \mathrm{mol}$ of $\mathrm{K}^{+}$. This value may be converted to $\mathrm{mg}$ of cytosolic protcin/ $\mathrm{ml}$ of cytosol, assuming a cytosolic $\mathrm{K}^{+}$concentration of $160 \mu \mathrm{mol} / \mathrm{ml}$ (Williams \& Woodbury, 1971; Christensen \& Folke, 1984). According to Weibel et al. (1969) the rat liver contains $0.444 \mathrm{ml}$ of cytosolic groundsubstance $/ \mathrm{g}$ of liver wet wt. Thus the conversion factor is:

mg of total protein/g of liver biopsy wet. wt

$\mathrm{mg}$ of eluate protcin/ $/ \mathrm{mol}$ of $\mathrm{K}^{+} \times 160 \times 0.44$

According to the model of the liver microcirculation shown in Fig. 1, we may now write:

$$
A_{\mathrm{Bi}}=v A_{\mathrm{po}}+(1-v) A_{\mathrm{py}}
$$

where $v$ is the volume fraction of the hepatocytes where the specific activity of the enzyme in question is $A_{\mathrm{p} p}$ (i.c. the specific activity found in periportal (eluate), and conversely $(1-v)$ the volume fraction where the activity is $A_{\mathrm{py}} \cdot A_{\mathrm{bi}}$ is the specific activity in the biopsy expressed as units/mg of cytosolic protein, calculated as explained above. Applying cyn. (1) to the two highly zonatcd enzymes, alanine aminotransferase and glutamine synthase (data from Table 4, Quistorff \& Grunnet, 1987), $v$ may be calculated to be $0.85 \pm 0.04$ and $0.52 \pm 0.12$, respectively. Thus for gluta- mine syrthase $15 \%$ of the hepatocytes contain $>99 \%$ of the activity. Gebhardt \& Mecke (1983) found this fraction to be approx. 7\%, using immunohistochemical techniques. For alanine aminotransferase the calculation indicates that the high and low activity of the enzyme is distributed in cell populations of almost equal sizc. However, redefining the model of Fig. 1 and allowing for a continuous enzyme activity gradient, the result would be compatible with a lincar periportal-perivenous gradient of alanine aminotransferase, as was indecd suggested by the results of Morrison et al. (1965) in microdissection studies.

I thank Lissi Immerdal for skilful technical assistance. Part of this investigation was supporled by Slatens Lagevidenskahelige Forskningsrăd and T. Holins Fond.

Cook. G. A.. Gallionc. U. H. Evan, A. P. \& IIarris. R. A. (1983) Biochim. Biophis. Acta 763, 356-367

Christensen. L. Ø. \& Folke, M. (1984) Biochem. J. 22. 265-268

de Duve. C. (1971) J. Cell. Biol. 50, 20D-55D

Gebhardt, R. \& Mecke, D. (1983) EMBO .I. 2. 567.570

Ḧ̈ussinger, D. (1983) Eur. J. Biochem. 133. 269-275

Jungermann, K. \& Katz, N. (1982) /lepatology 2, 385-395

Lillic, R. D. (1940) Stain Technol. 15, 17.22

Lindros, K. O. \& Penttilä, K. E. (1985) Biochem. J. 228. 757-760

Lowry, O. H., Rosebrough, N. J., Farr, A. L. \& Randall, R. J. (1951) J. Biol. Chem. 193, 265-275

Morrison, G. R., Brock, F. E., Karl, I. E. \& Shank, R. E. (1965) Arch. Binchem. Biophys. 111. 448460

Pösö. A. R.. Penttilä, K. S.. Suolinna, E. H. \& Lindros, K. O. (1986) Biochem. J. 239, 262-267

Poulsen, H. \& Christoftersen, P. (1979) Allas of Lirer Biopsies. pp. 14. 219. 222, Munksgard and Lippencotl, Copenhagen Pliiladelphia

Quistorf, B. (1985) Biochem. J. 229, 221-226

Quistorff; B. \& Grunnet, N. (1987) Biochem. J. 243.87 95

Quistorfi. B., Grumnel, N. \& Cornell, N. W. (1985) Biochem. J. 226. 289-297

QuistorlF, B., Dich, J. \& Grunne1, N. (1986) Biochem. Biophys. Re's. Commin. 139, 1055-1061

Weibel, E. R., Stüubli, W. Gnägi, H. R.\& Iless, F. H. (1969) J. Cell Biol. 42, 68-91

Williams. J. A. \& Woodbury, D. M. (1971) J. Physiol. (Lomson) 212. 8599

Received 29 December 1986

\section{Oxygen gradients: the problem of hypoxia}

HERBERT DE GROOT and THOMAS NOLL Institut für Physiologische Chemie I der Universität Düsseldorf, Moorenstrasse 5, D-4000 Dïsseldorf, Federal Republic of Germany

\section{Oxygen gradients in liver}

Duc to $\mathrm{O}_{2}$ consumption inter- and intrancellular $\mathrm{O}_{2}$ gradients are formed in tissues. In liver there are steep intercellular $\mathrm{O}_{2}$ gradients along the sinusoids from the portal to the central regions of the liver lobules (Sics, 1977; Ji el al., 1982). As demonstrated by use of micro-needle clectrodes and multivire surface electrodes, the actual $\mathrm{pO}_{2}$ in liver ranges betwcen 1 and $60 \mathrm{mmHg}$ witb mean values around $22 \mathrm{mmHg}$ (Fig. 1).

From comparison of $p \mathrm{O}_{2}$ of hall-maximal changes $\left(p_{s 0}\right.$ values) of oxidation-reduction states of cytochrome $c$ in isolated liver cells and mitochondria, Jones (1984) estimated an intracellular $\mathrm{O}_{2}$ gradient of about $4 \mathrm{mmHg}$ from the extracellular medium towards the outer mitochondrial membrane under $\mathrm{O}_{2}$-limiting conditions. From the $\mathrm{O}_{2}$ dependence of the hepatocellular $\mathrm{O}_{2}$ uptake (Fig. 1) an $\mathrm{O}_{2}$ gradient of maximally $5 \mathrm{mml}$ from the extraeellular space towards the mitochondrial membrane can be conclnded. Comparison of $p_{50}$ values of the metabolism of two substrates of cytochrome $P-450$ by isolated hepatocytes and isolated lives microsomes (Jones \& Mason, 1978) as well as the comparison of the optimum $p \mathrm{O}_{2}$ Cor the induction of lipid peroxidation by carbon tetrachloride $\left(\mathrm{CCl}_{\mathrm{i}}\right)$, again in isolated hepatocytes and isolated microsomes (de Groot \& Noll, 1986: Noll \& de Groot, 1984), reveal that $\mathrm{O}_{2}$ gradients from the extracellular medium to cellular compartments other than mitochondria appear to be below the detection limit. Thus within the liver cell a significant $\mathrm{O}_{2}$ gradient appears to cxist only towards the mitochondrial compartment and. furthermore, this $\mathrm{O}_{2}$ gradient must be predominantly at the regions immediately surrounding the mitochondria.

\section{Oxystat system}

As pointed out, steep intercellular $\mathrm{O}_{2}$ gradients cxist between the various cells of the intact liver. Therciore, isolated liver cells and subcellular rractions are the preferred biological systems for the study of the response of hepatocellular functions to different $\mathrm{O}_{2}$ conditions. We have developed a special incubation apparatus for isolated cells and subcellular fractions, the oxystat system, which com- 


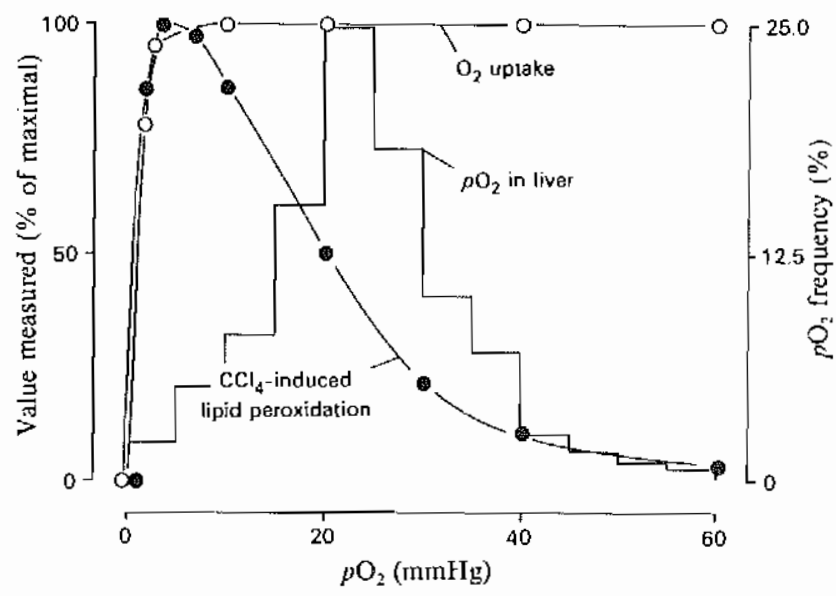

Fig. 1. $\mathrm{O}_{2}$ dependence of hepatocellular $\mathrm{O}_{2}$ uptake and $\mathrm{CCl}_{4}^{-}$ induced lipid peroxidation

$\mathrm{O}_{2}$ uptake and lipid peroxidation in hepatocytes were determined as previously described (de Groot \& Noll, 1984; de Groot el al., 1985). For comparison, the $p \mathrm{O}_{2}$ frequency distribution curve of the liver in situ is ineluded (Kessler et al., 1973).

bines the advantage to maintain steady state $p \mathrm{O}_{2}$ with high precision from $300 \mathrm{mmHg}$ down to $0.01 \mathrm{mmHg}$ with the capability lo monitor $\mathrm{O}_{2}$ uptake simultaneously (Noll et al., $1986,1987)$. In contrast to the more commonly used manometric technique, the oxystat system maintains $\mathrm{O}_{2}$ supply by injection of $\mathrm{O}_{2}$ dissolved in aqueous solution. The actual $p \mathrm{O}_{2}$ in the incubation chamber is continuously monitored by either a Clark-type electrode (at $p \mathrm{O}_{2} \geqslant 0.2 \mathrm{mmHg}$ ) or by an $\mathrm{O}_{2}$ sensor based on the $\mathrm{O}_{2}$ dependence of bacterial luminescence (at $p \mathrm{O}_{2}<0.2 \mathrm{mmHg}$ ). The oxystat system represents a fecdback eontrol circuit supported by a computer which reads the $\mathrm{O}_{2}$ sensor signals, compares them with a preselected value, and triggers a motor-driven piston burette to deliver $\mathrm{O}_{2}$-saturated medium in to the reaction chamber until the setpoint is reached. Further, it calculates the $\mathrm{O}_{2}$ uptake from the amounts of $\mathrm{O}_{2}$-saturated medium added.

\section{Oxygen dependence of liver cell finctions}

The study of the $\mathrm{O}_{2}$ dependence of mammalian cell functions usually reveals that most of them only respond to decreases of the $p \mathrm{O}_{2}$ when a characteristie threshold value has been passed. A typical example is the $\mathrm{O}_{2}$ uptake of the isolated liver ccll (Fig. 1). Its rate is almost constant within a $p \mathrm{O}_{2}$ range of $5-100 \mathrm{mmHg}$. Bclow the critical $p \mathrm{O}_{2}$ of $5 \mathrm{mmHg}$, however, the rate of $\mathrm{O}_{2}$ uptake starts to decrease and it is half-maximal at a $p \mathrm{O}_{2}$ of $0.5 \mathrm{mmHg}$. Since hepatocellular $\mathrm{O}_{2}$ uptake reflects more than $90 \%$ of the electron How through the mitochondrial respiratory chain (de Groot et al., 1985) and in that way is a dircet function of the energy (ATP) turnover of the cell, the decrease of the $\mathrm{O}_{2}$ uptake rate indicates an equivalent decrease of the cnergy-consuming functions of the cell.

It is known that a decreased $p \mathrm{O}_{2}$ is paralleled by decreases in the ATP/ADP and NAD/NADH coneentration ratios and by an increase in the reduction state of components of the mitochondrial respiratory chain such as cytochrome $c$ and cytochrome $a a_{3}$ (e.g. Oshino et al., 1974; Wilson et al., 1979). Experiments in isolated liver cells, performed under steady state $p \mathrm{O}_{2}$ in the oxystat system, reveal that the decrease in the ATP/ADP concentration ratio is espeeially prominent at $\mathrm{pO}_{2}$ below $5 \mathrm{mmHg}$ in line with the impairment of energy supply at $p \mathrm{O}_{2}$ below $5 \mathrm{mmHg}$, as described above. The ATP/ADP concentration ratio started from
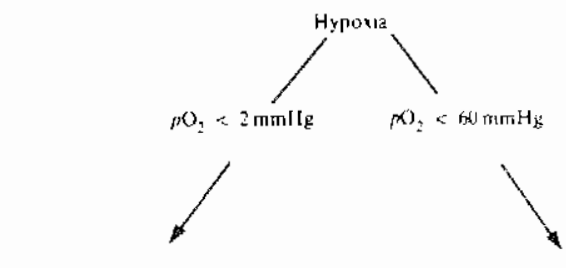

$\mathrm{O}_{2}$ limitation of sytochrome oxidase iunction

Inereuse of rejulate atiation oi haloalkanes lo icaction free radicals

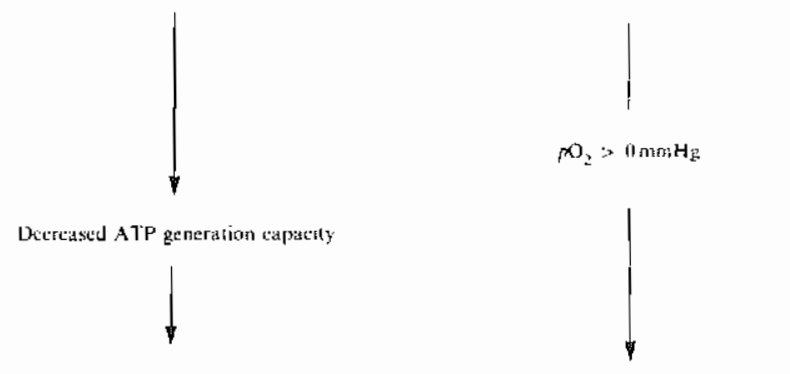

Decreised membranc coupled ion transiscation $\left(\mathrm{K}^{+} . \mathrm{Na}^{+} \cdot \mathrm{Ca}^{2+}\right)$ incressed inositol trisphosphase, dacylglyecrol
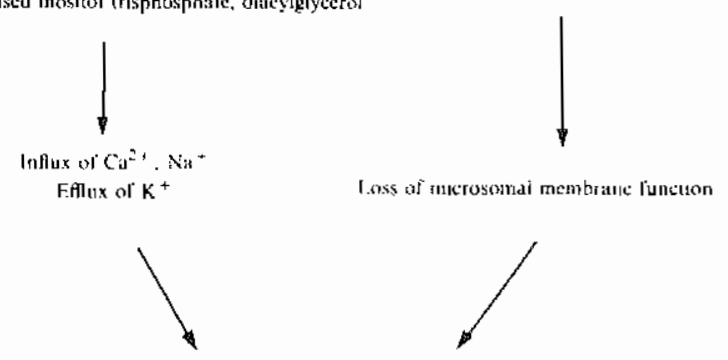

Loss of iniracellular son homacostasis Disturbance of membranc potential Increase of cylosolic $\mathrm{Ca}^{2+}$

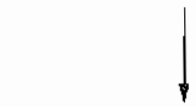

Actwation ol phospholipases $\left\{A_{1}, A_{2} .(c)\right.$ and proteinuses:<smiles>[3H]I</smiles>

Disrupios of the ectl membrane struselure

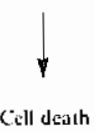

Fig 2. Possible mechanisms of cell death caused by $\mathrm{O}_{2}$ limiration of cytochrome oxidase function and by an increased reductive activation of haloalkanes, such as $\mathrm{CCl}_{4}$ and halothane, under hypoxia

values above 10 at a $p \mathrm{O}_{2}$ of $100 \mathrm{mmHg}$, decreased slowly to values of 7-8 at $p \mathrm{O}_{2}$ of $5 \mathrm{mmHg}$, but then abruptly dropped to values of aboul 1 under anaerobic conditions (data not shown).

Decreasing $p \mathrm{O}_{2}$ are not necessarily combined with decreasing cell functions. In fact, certain functions increase with decreasing $p \mathrm{O}_{2}$ or even become feasible only at low $p \mathrm{O}_{2}$. One remarkable example is the reductive metabolism of halogenated alkanes such as $\mathrm{CCl}_{4}$ and the anaesthetic halothane $\left(\mathrm{CF}_{3} \mathrm{CHBrCl}\right)$ (de Groot \& Noll, 1983, 1986). The metabolism of these well known hepatotoxins is 